\title{
One-eye-set sugarcane susceptibility to weed interference
}

\author{
LUCAS R. BELUCI ${ }^{1}$, ALLAN L. BACHA ${ }^{1}$, ARTHUR A.M. BARROSO ${ }^{2}$ and PEDRO LUIS C.A. ALVES \\ ${ }^{1}$ Universidade Estadual Paulista/UNESP/FCAV, Departamento de Biologia Aplicada à Agropecuária, \\ Via de Acesso Prof. Paulo Donato Castellane, s/n, 14884-900 Jaboticabal, SP, Brazil \\ ${ }^{2}$ Universidade Federal do Paraná/UFPR, Departamento de Fitotecnia e Fitossanitarismo, \\ Rua dos Funcionários, 1540, 80035-050 Curitiba, PR, Brazil
}

Manuscript received on February 19, 2018; accepted for publication on April 4, 2018

\begin{abstract}
The new technology of sugarcane planting, known as one-eye-set seedlings, offer a high standard of plant health and vegetative vigor. However, there are no reports in the literature that evaluate the weed competition with one-eye-set sugarcane seedlings, and the periods in which weed communities need to be controlled in this system. Two interference experiments were conducted in field conditions. The first experiment determined the periods of weed interference of an infesting community predominated by Ipomoea hederifolia and Merremia aegyptia in sugarcane. In the second experiment, these same species competed with plants of the same sugarcane cultivar. Productivity and qualitative aspects of production were evaluated. The critical period of interference prevention in one-eye-set sugarcane system was 103 days, with weed community interference starting at 35 days and lasting until 138 days after planting. Weed coexistence during the entire sugarcane cycle reduced productivity by $60 \%$ and affected qualitative characteristics such as the total reducing sugars. Both species affected the vegetative development of the crop, mainly the tillering. I. hederifolia plants developed ahead of the M. aegyptia plants but in late evaluations the interference caused by M. aegyptia $(77 \%)$ was greater $(P<0.01)$ than that caused by $I$. hederifolia (72\%).
\end{abstract}

Key words: critical period of interference prevention, competition, morning glory species, periods of interference, sugarcane OES.

\section{INTRODUCTION}

Brazil is the largest producer of sugarcane in the world. A total of 647.6 million tons of cane are produced annually in an area of approximately $8,838.5$ thousand hectares. The average productivity of sugarcane is $73 \mathrm{t} \mathrm{ha}^{-1}$, higher than the world average of $65 \mathrm{t} \mathrm{ha}^{-1}$. One explanation for the great

Correspondence to: Allan Lopes Bacha

E-mail: allan_lb@hotmail.com productivity is the new technologies that are being developed and applied in the Brazilian production system (Conab 2017). One of these technologies is a system that uses pre-budded seedlings for sugarcane, which is also known as one-eye-set (OES), where the multiplication of the crop occurs in nurseries. These seedlings are derived from individualized buds, originating from cane stems, combining a high standard of plant health and 
vegetative vigor. The use of this system provides a reduction in the material at the time of planting, from $15 \mathrm{tha}^{-1}$ (used in the conventional system) to $1.5 \mathrm{t} \mathrm{ha}^{-1}$, thus ensuring a better distribution of the plants in the area, less intraspecific competition, and greater seedling survival in the field (Landell et al. 2013). Other countries are adopting this technology such as India, China and Australia.

The negative effect of the presence of weeds in areas of sugarcane is widely known (Lencse and Griffin 1991, Dalley and Richard Jr 2007, Bhullar et al. 2012). These plants, when present in the field, will negatively affect crop growth because they compete for water, light, and nutrients, and release allelopathic compounds into the environment (Kuva et al. 2007). In this sense, the weed community harms both the quality and quantity of the raw material (Takim et al. 2014). Regarding productivity, weed interference causes losses of up to $82 \%$, depending on the weed species and the production system adopted (ratoon or plant sugarcane) (Kuva et al. 2000, 2007, Meirelles et al. 2009, Silva et al. 2009, Piza 2016).

Among these weeds, species of the genera Merremia and Ipomoea stand out as problems in sugarcane because, in addition to competing for resources, they hinder and reduce the yield of the mechanized harvesting process (Azania et al. 2002). The selection of these species occurred due to the prohibition of cane field burning, after which a strategy of placing a layer of straw on the soil was used instead of burning. These species have seeds with high nutritional reserves and can overcome this barrier and emerge (Martins et al. 1999, Cavenaghi et al. 2007, Negrissoli et al. 2007, Correia and Kronka 2010).

Several factors affect the degree of interference of the weed community in the crop; however, the time and period of coexistence between the weeds and the crop are of extreme importance, as they can guide the choice of management practices, resulting in more effective control (Khan et al.
2004). In this context, Pitelli and Durigan (1984) noted three periods of interference, which are the Period Before Interference (PBI), when the crop can live with weeds without significant reductions in productivity; the Total Period of Interference Prevention (TPIP), which is the total period in which weeds must be controlled, so the crop can manifest its full productive potential; and the Critical Period of Interference Prevention (CPIP), which is the interval between the PBI and the TPIP. Several studies have demonstrated the periods of weed interference for conventional sugarcane plantation systems (Kuva et al. 2000, 2001, 2003, 2007, Meirelles et al. 2009, Silva et al. 2009). However, no studies have elucidated such periods of interference for the OES system, justifying the need for work in this direction.

Therefore, due to the importance of the genus Ipomoea sp. and Merremia sp. in infestations in sugarcane, as well as the lack of information on the response of the OES planting system to the competition imposed by weeds, the objectives of this study were to establish the periods of weed interference in the productivity and quality of production of OES sugarcane and quantify the plant-specific interference of Ipomoea hederifolia and Merremia aegyptia with the crop.

\section{MATERIALS AND METHODS}

\section{WEED INTERFERENCE PERIODS IN ONE-EYE-SET SUGARCANE}

\section{Plant Materials}

The experiment was carried out in field conditions in the municipality of Nova Europa, São Paulo state (SP), Brazil $\left(21.92^{\circ} \mathrm{S}, 48.60^{\circ} \mathrm{W}\right)$, between 2015 and 2016. The area belongs to the Santa Fé sugarcane industry, which had a clay soil with the following chemical characteristics: $5.4 \mathrm{pH}\left(\mathrm{CaCl}_{2}\right)$; $30 \mathrm{~g} \mathrm{dm}^{-3} \mathrm{MO} ; 26 \mathrm{mg} \mathrm{dm}^{-3} \mathrm{p}$ (resin); $\mathrm{V}(\%)$ of $62 \%$; and $7.5,32,16,34,55.5$, and $89.5 \mathrm{mmol}_{\mathrm{c}} \mathrm{dm}^{-3}$ 
$\mathrm{K}^{+}, \mathrm{Ca}^{2+}, \mathrm{Mg}^{2+}, \mathrm{H}^{+} \mathrm{Al}^{3+}, \mathrm{SB}$, and $\mathrm{T}$, respectively. According to the Köppen (1948) classification, the climate of the site is subtropical type Cwa, with an annual average precipitation of 1,314 $\mathrm{mm}$; dry winters; rainy summers; an average temperature of $21.7^{\circ} \mathrm{C}$; and altitude of $496 \mathrm{~m}$.

The sugarcane OES of cultivar RB86-7515 (Plene $\mathrm{PB}^{\circledR}$, Syngenta ${ }^{\circledR}$, Itápolis, Brazil) presented, on average, four leaves and a tiller at the time of planting. The planting process was carried out manually, with spacing of $1.5 \mathrm{~m}$ by $0.5 \mathrm{~m}$ in a previously grooved area. On the day of installation of the experiment, the area was free of weed infestation. Soil samples were collected at ten points from across the total area for collection of the seed bank, and the main breeding structures were found for M. aegyptia and I. hederifolia (6 and 5.8 million seeds ha $^{-1}$, respectively).

\section{Experimental Treatments}

The treatments were represented by two groups periods without weed control or with control from emergence to crop harvesting. These periods corresponded to $0,16,30,37,51,72,93,114,135$, and 183 days after emergence (DAE). In the first group (coexistence), at the end of each evaluated period, the weeds were removed by hand weeding. In the second group (control), the weeds were weeded from emergence until the end of this period. Each plot consisted of four planting rows, with inter-row spacing of $1.5 \mathrm{~m}$ and length of 8 $\mathrm{m}$. For the usable plot area, the two central rows were considered, with one meter at the ends being disregarded and with each plot totaling $18 \mathrm{~m}^{2}$. Each treatment was repeated four times.

\section{Evaluations and Data Analysis}

The weed community was evaluated at the end of each coexistence period and at 376 days for all control periods, with two samples of emerged plants being collected from a $0.25 \mathrm{~m}^{2}$ area using 0.5 by
$0.5 \mathrm{~m}$ sample squares placed randomly within each plot. In these periods, the weeds were identified, collected, and had their dry matter quantified by drying in a forced air oven, at $65^{\circ} \mathrm{C}$ for $72 \mathrm{~h}$. Based on the data for relative constancy, relative density, and relative dominance, the relative importance of the major species of the weed community was calculated (Mueller-Dombois and Ellenberg 1974).

For the sugarcane, at the end of the experimental period, ten stems per plot were collected to estimate the yield. The total number of stems per plot was also counted, and the results were estimated for TSH (tons of stems per hectare). The collected bundles were blunted to ensure better evaluations, then taken to the laboratory for technological analysis to obtain the following variables: Fiber, Brix, Pol, purity, and TRS (total reducing sugars). The data were submitted to ANOVA by the F test, that when significative, means were compared by the Tukey test at the 5\% probability level.

For determination of the periods of interference (PBI, TPIP, and CPIP) using the Origin 9 program (MicroCal), the productivity data were submitted to regression analysis by the Boltzmann sigmoidal model adapted by Kuva et al. (2000), considering losses of 5\% of productivity as acceptable (Equation 1).

$$
Y=(A 1-A 2) / 1+e^{(x-x 0) / d x}+A 2
$$

where sugarcane production $(Y)$ is equal to the difference between the maximum $(A 1)$ and minimum (A2) production of the sugarcane, divided by the interaction between the upper limit of the control period or coexistence period $(\mathrm{x})$, the average value between the maximum and minimum production, and the speed of loss or gain of production $(\mathrm{dx})$.

\section{Ipomoea hederifolia AND Merremia aegyptia INTERFERENCE IN THE INITIAL DEVELOPMENT OF ONE-EYE-SET SUGARCANE}

\section{Plant Materials}

The experiment was conducted in 2015 in an open and semi-controlled area in Jaboticabal, SP, Brazil 


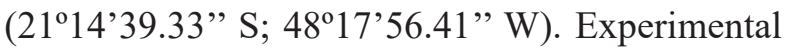
units used were bottomless cement border vessels presenting $1.3 \mathrm{~m}^{2}$ area separated between them by $0.5 \mathrm{~cm}$, whose texture was composed of $38 \%$ clay, $55 \%$ sand, and $7 \%$ silt, with the following chemical composition: $\mathrm{pH} 5.8\left(\mathrm{CaCl}_{2}\right) ; 22 \mathrm{~g} \mathrm{dm}^{-3}$ of organic matter; $76 \% \mathrm{~V} \%$; $76 \mathrm{mg} \mathrm{dm}^{-3} \mathrm{p}$ (resin); and 3.3, 45,14 , and $20 \mathrm{mmol}_{\mathrm{c}} \mathrm{dm}^{-3}$, respectively, of $\mathrm{K}, \mathrm{Ca}$, $\mathrm{Mg}$ and $\mathrm{H}+\mathrm{Al}$. According to the Köppen (1948) classification, the climate of the site is of type Cwa, subtropical, with an annual precipitation average of $1,552 \mathrm{~mm}$; dry winters; rainy summers; an average temperature of $22{ }^{\circ} \mathrm{C}$; and altitude of $592 \mathrm{~m}$. The sugarcane used was one-eye-set RB86-7515, provided by Syngenta ${ }^{\circledR}$ (Itápolis, Brazil), and $I$. hederifolia and M. aegyptia seeds were purchased locally.

\section{Experimental Treatments and Statistical Analysis}

A fully randomized design with three treatments and six replicates was used. The treatments consisted of 1) Control (OES not coexisting with weeds); 2) OES in coexistence with I. hederifolia; and 3) OES in coexistence with $M$. aegyptia. The sugarcane seedlings were planted in rows with spacing of 0.5 $\mathrm{m}$ between plants, totaling two sugarcane seedlings per pot. In the coexistence plots, four seedlings of $I$. hederifolia or M. aegyptia were transplanted per experimental plot, equivalent to a density of 3 plants $\mathrm{m}^{-2}$. The seedlings of I. hederifolia and M. aegyptia were obtained by sowing seeds on a vegetable growing tray to standardize their size and transplanting after a pair of fully expanded leaves.

At $29,50,71,85,109$, and 184 days after planting (DAP), the height of the main tiller and the number of tillers per plant were evaluated. The height of the main tiller, from the soil to the last fully developed auricle, which was previously demarcated, was averaged by experimental unit. The tillers were counted visually and extrapolated per plant. At 184 DAP, the end of the experimental period, the aerial parts of the sugarcane and the weed tendrils were cut near the soil surface, separated, and dried in a forced air oven until reaching constant weight. They were then weighed using a precision scale.

The dry matter data were submitted to ANOVA by the $\mathrm{F}$ test, and the means were compared by the Tukey test at the $5 \%$ probability level. The height data were submitted to nonlinear regression analysis of the exponential type, and the tiller number was submitted to log-logistic nonlinear regression analysis using the software Origin 9 (MicroCal).

\section{RESULTS}

Between the two experiments, conducted in different locations, environmental data was close for them in all observed variables. In experiment one (Exp1, conducted in Nova Europa), the average temperature was lower than in experiment two (Exp2, conducted in Jaboticabal). Instead, the relative humidity, precipitation and irradiance were little higher in Nova Europa, Exp1 (Table I).

As these differences were small, we should assume that observed data between trials function as a repetition of the weeds interference quantification.

\section{WEED INTERFERENCE PERIODS IN ONE-EYE-SET SUGARCANE}

In the situation of increasing periods of coexistence, a greater relative importance was initially observed for species other than I. hederifolia and M. aegyptia (Figure 1).

In this initial period, several species of the Poaceae family were more important probably because the seeds were closer to the soil surface and germinated quickly. Subsequently, $I$. hederifolia became the most important species in the community at 37 days after emergence (DAE) and retained that importance up to 93 DAE. After that point, $M$. aegyptia assumed the dominant position in the community and predominated 
TABLE I

Environmental variables during the two experiments, 2015.

\begin{tabular}{cccccccccc}
\hline \multirow{2}{*}{ Month } & \multicolumn{2}{c}{ Tave $\left({ }^{\circ} \mathrm{C}\right)$} & \multicolumn{2}{c}{ RH (\%) } & \multicolumn{2}{c}{ Precipitation (mm) } & \multicolumn{2}{c}{ Irradiance (h) } \\
\cline { 2 - 9 } & Exp1 & Exp2 & Exp1 & Exp2 & Exp1 & Exp2 & Exp1 & Exp2 \\
\hline January & 26.5 & 27.1 & 68.4 & 74.3 & 101.5 & 140.0 & 270.2 & 214.9 \\
February & 24.3 & 25.0 & 78.8 & 74.4 & 283.7 & 165.2 & 185.0 & 157.0 \\
March & 23.3 & 23.7 & 83.5 & 75.9 & 183.3 & 269.8 & 148.3 & 116.0 \\
April & 22.9 & 23.4 & 76.9 & 74.0 & 86.4 & 37.6 & 234.5 & 192.5 \\
May & 20.0 & 20.6 & 79.5 & 74.0 & 98.0 & 148.6 & 180.9 & 154.2 \\
June & 19.7 & 20.6 & 73.5 & 73.8 & 11.6 & 1.0 & 239.3 & 209.9 \\
July & 19.7 & 20.2 & 74.3 & 67.1 & 45.0 & 77.8 & 189.4 & 165.5 \\
August & 21.3 & 22.2 & 56.0 & 57.8 & 4.4 & 13.0 & 283.4 & 252.1 \\
September & 23.8 & 24.4 & 64.5 & 61.1 & 120.2 & 123.6 & 208.5 & 183.5 \\
October & 25.8 & 25.8 & 62.1 & 63.7 & 149.7 & 129.8 & 231.6 & 200.3 \\
November & 24.8 & 24.8 & 78.0 & 68.5 & 255.8 & 339.4 & 189.2 & 129.1 \\
December & 24.8 & 25.5 & 78.6 & 72.4 & 372.3 & 186.0 & 155.8 & 126.9 \\
Year & 23.1 & 25.0 & 72.8 & 69.8 & $1,711.9$ & $1,631.8$ & $2,516.1$ & $2,101.9$ \\
\hline
\end{tabular}

Tave: average temperature, RH: relative humidity of air, Exp1 = Nova Europa-SP, Brazil, Exp2 = Jaboticabal-SP, Brazil.

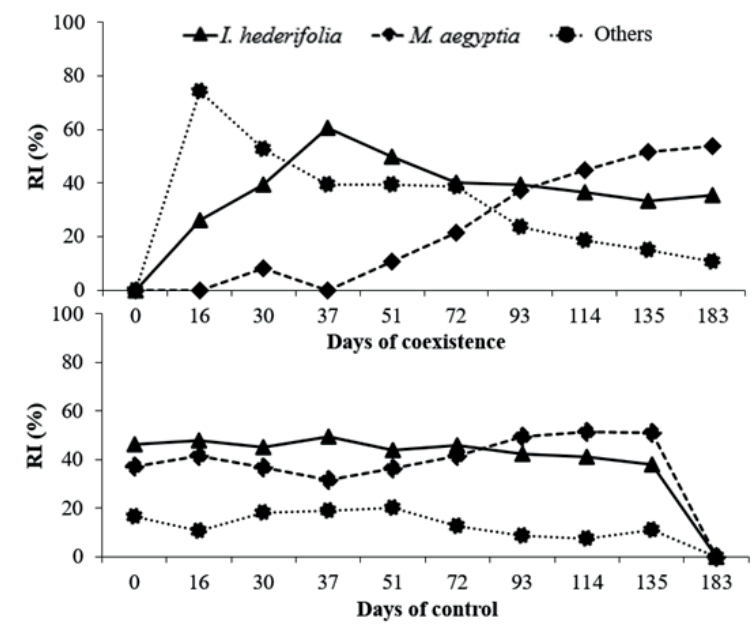

Figure 1 - Relative importance (RI) of the main weeds ( $\Delta I$. hederifolia, M. aegyptia, and $\bullet$ others) present in the weed community of pre-budded sugarcane in periods of coexistence and control.

until the end of the evaluation period. In periods of increasing control, I. hederifolia was the most important species of the community until 72 days after planting (DAP), when M. aegyptia assumed that position (Figure 1).

Regarding cane production, the longer the coexistence period between species, the greater the reduction in productivity. Conversely, as the control period was increased, the productivity increased (Figure 2).

With a loss of $5 \%$ in crop productivity considered acceptable, the period before interference (PBI) of the weed community in the OES sugarcane was estimated to extend to 35 DAP. The total period of interference prevention (TPIP), estimated to extend to 138 DAP, resulted in a critical period of prevention of interference (CPIP) of 103 days (from 35 to 138 DAP). When the crop spent the entire experimental period competing with weeds, the yield loss was approximately $60 \%$ (Figure 2).

In the analysis of the qualitative characteristics of the sugarcane, with an increase in the coexistence periods, a significant increase was observed in the fiber $(12 \%)$ of the sugarcane (Table II).

The other parameters were all reduced (Brix, Pol, purity, and TRS); these reductions were $28.6 \%$, $34.3 \%, 18.3 \%$, and $33.3 \%$, respectively. With the increase in the control periods, an inverse behavior was observed, i.e., a reduction in fiber percentage 


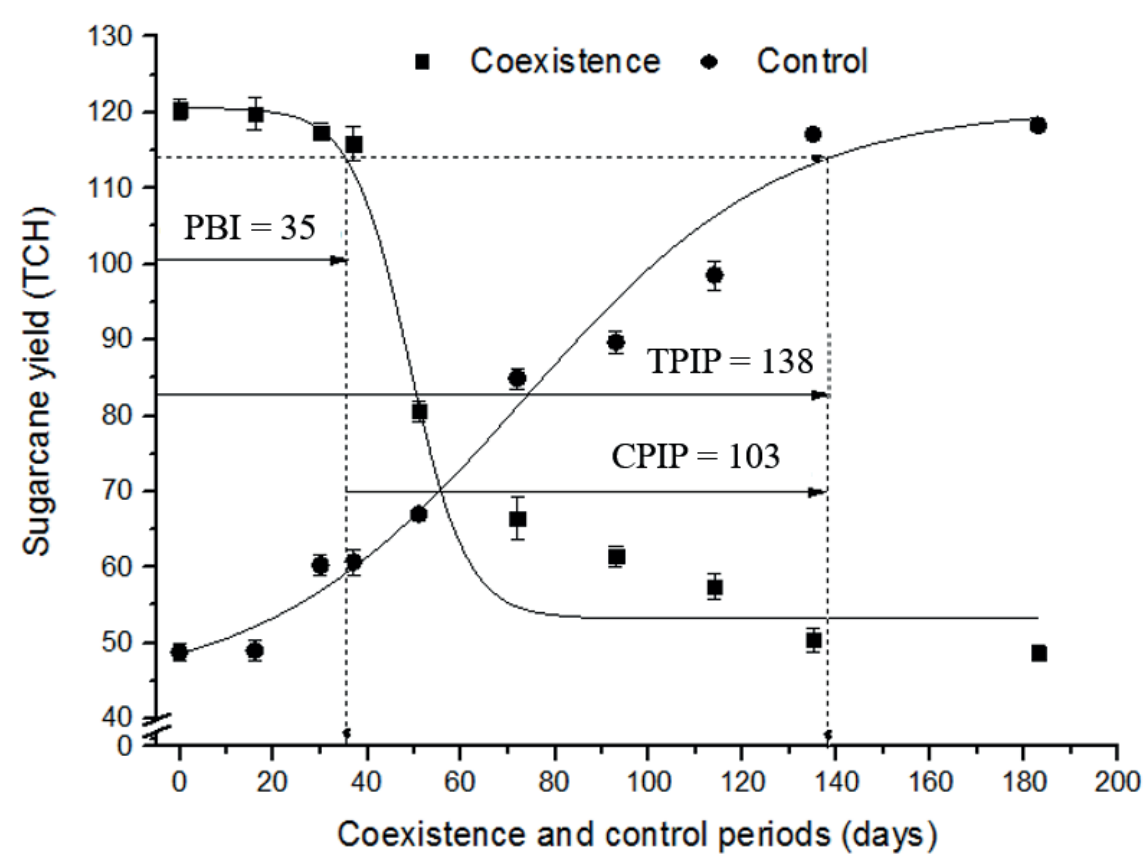

Figure 2 - Graph of the critical period of interference prevention (CPIP), total period of interference prevention (TPIP), and period before interference (PBI), assuming a $5 \%$ reduction in the productivity of the sugarcane crop, according to management criteria with weed control and weed coexistence. Weed coexistence: $y=120.62$ $53.26 / 1+\left(\mathrm{e}^{\wedge}(\mathrm{x}-48.93) / 6.11\right)+53.26, \mathrm{R}^{2}=0.97$; Weed control: $\mathrm{y}=43.25-120.73 / 1+\left(\mathrm{e}^{\wedge}(\mathrm{x}\right.$ $73.26) / 27.70)+120.73, R^{2}=0.98$. Vertical bars denote the error of the mean $(n=4)$.

$(12.2 \%)$ and an increase in Brix (40.2\%), Pol (52.2\%), purity $(22,4 \%)$, and TRS $(47.7 \%)$ (Table III).

\section{Ipomoea hederifolia AND Merremia aegyptia INTERFERENCE IN THE INITIAL DEVELOPMENT OF ONE-EYE-SET SUGARCANE}

The coexistence of OES sugarcane with $I$. hederifolia and M. aegyptia plants did not result in harmful effects on plant height at the initial periods of crop growth (up to 100 DAP) (Figure 3).

After this period, weed interference in sugarcane growth was observed, which increased up to the end of the evaluated period. At 184 DAP, a reduction in height was observed in the sugarcane growth in coexistence with $I$. hederifolia and $M$. aegyptia of $36.2 \%$ and $39.4 \%$, respectively. Regarding the two weed species, both interfered in a similar way in the culture.
For the tiller number, the results were different. The weeds affected cane tillering starting at 50 DAP (Figure 3). Greater interference by M. aegyptia compared to I. hederifolia was observed starting at 120 DAP. On average, the species interfered in $70 \%$ of the formation of sugarcane tillers.

For the dry mass of sugarcane plants collected at 135 DAP, I. hederifolia and M. aegyptia also interfered in the growth of the crop. The losses in coexistence with $I$. hederifolia and $M$. aegyptia were $76.8 \%$ and $72.1 \%$, respectively, compared to the control group (502.4 g/shoot) (Figure 4). However, for the dry mass of the weed community, the $M$. aegyptia plants developed $9.4 \%$ less than the I. hederifolia (data not shown). At 184 DAP, weeds showed different levels of interference in the crop. The coexistence of sugarcane with $M$. aegyptia plants caused greater reductions in the development of the crop, reaching $77 \%$ losses in the aerial dry mass of the plants, whereas the 
TABLE II

Effects of weed community coexisting periods on the qualitative characteristics of RB86-7515 sugarcane evaluated at 376 days after planting.

\begin{tabular}{|c|c|c|c|c|c|}
\hline $\begin{array}{c}\text { Days of } \\
\text { coexistence }\end{array}$ & Fiber (\%) & Brix (\%) & POL (\%) & Purity (\%) & TRS (kg/T) \\
\hline 0 & $10.2 \mathrm{c}$ & $19.9 \mathrm{a}$ & $17.5 \mathrm{a}$ & $88.0 \mathrm{a}$ & $148.4 \mathrm{a}$ \\
\hline 16 & $10.5 \mathrm{c}$ & $19.0 \mathrm{~b}$ & $16.3 \mathrm{~b}$ & $86.2 \mathrm{~b}$ & $139.1 \mathrm{~b}$ \\
\hline 30 & $10.6 \mathrm{~b}$ & $18.2 \mathrm{c}$ & $15.4 \mathrm{c}$ & $84.6 \mathrm{bc}$ & $132.6 \mathrm{c}$ \\
\hline 37 & $10.7 \mathrm{~b}$ & $17.6 \mathrm{c}$ & $14.6 \mathrm{c}$ & $83.4 \mathrm{~cd}$ & $127.8 \mathrm{~d}$ \\
\hline 51 & $10.9 \mathrm{~b}$ & $17.4 \mathrm{~d}$ & $14.4 \mathrm{~d}$ & 82.9 cde & $125.6 \mathrm{~d}$ \\
\hline 72 & $11.0 \mathrm{~b}$ & $17.1 \mathrm{~d}$ & $14.2 \mathrm{~d}$ & $82.3 \mathrm{de}$ & $124.5 \mathrm{~d}$ \\
\hline 93 & $11.1 \mathrm{~b}$ & $16.5 \mathrm{de}$ & $13.8 \mathrm{de}$ & $81.3 \mathrm{ef}$ & $120.3 \mathrm{e}$ \\
\hline 114 & $11.3 \mathrm{~b}$ & $15.8 \mathrm{e}$ & $13.1 \mathrm{ef}$ & $79.8 \mathrm{f}$ & $113.5 \mathrm{f}$ \\
\hline 135 & $11.5 \mathrm{~b}$ & $15.3 \mathrm{f}$ & $12.4 \mathrm{f}$ & $75.8 \mathrm{~g}$ & $108.3 \mathrm{~g}$ \\
\hline 183 & $11.6 \mathrm{a}$ & $14.2 \mathrm{~g}$ & $11.5 \mathrm{~g}$ & $71.9 \mathrm{~h}$ & $100.5 \mathrm{~h}$ \\
\hline $\mathrm{F}$ & $53.4 * *$ & $140.5^{* *}$ & $135.7 * *$ & $142.3 * *$ & $334.9 * *$ \\
\hline CV (\%) & 1.45 & 1.66 & 2.20 & 0.98 & 1.26 \\
\hline
\end{tabular}

** significant at the $1 \%$ probability level by the $\mathrm{F}$ test. Means followed by the same letter in a column do not differ from each other at the $5 \%$ probability level by the Tukey test. Brix = Sugar content (gram of sucrose in 100 grams of solution), POL $=$ Sucrose content expressed as percentage, $\mathrm{TRS}=$ Total reducing sugars, $\mathrm{CV}=$ coefficient of variation.

TABLE III

Effects of weed community control periods on the qualitative characteristics of RB86-7515 sugarcane evaluated at 376 days after planting.

\begin{tabular}{|c|c|c|c|c|c|}
\hline Days of control & Fiber (\%) & Brix (\%) & POL (\%) & Purity (\%) & TRS (kg/T) \\
\hline 0 & $11.5 \mathrm{a}$ & $14.2 \mathrm{~g}$ & $11.1 \mathrm{~g}$ & $71.8 \mathrm{~g}$ & $98.9 \mathrm{~h}$ \\
\hline 16 & $11.4 \mathrm{ab}$ & $15.2 \mathrm{f}$ & $12.4 \mathrm{f}$ & $75.8 \mathrm{f}$ & $107.2 \mathrm{~g}$ \\
\hline 30 & $11.2 \mathrm{~b}$ & 15.7 ef & $13.0 \mathrm{ef}$ & $79.8 \mathrm{e}$ & $112.4 \mathrm{f}$ \\
\hline 37 & $11.1 \mathrm{~b}$ & $16.3 \mathrm{de}$ & $13.6 \mathrm{de}$ & $81.3 \mathrm{de}$ & $119.2 \mathrm{e}$ \\
\hline 51 & $11.0 \mathrm{~b}$ & $17.2 \mathrm{~d}$ & $14.1 \mathrm{~d}$ & $82.3 \mathrm{~d}$ & $123.4 \mathrm{~d}$ \\
\hline 72 & $10.8 \mathrm{~b}$ & $17.4 \mathrm{~d}$ & $14.3 \mathrm{~d}$ & $82.9 \mathrm{~cd}$ & $124.5 \mathrm{~d}$ \\
\hline 93 & $10.7 \mathrm{~b}$ & $17.6 \mathrm{c}$ & $14.6 \mathrm{c}$ & $83.4 \mathrm{~cd}$ & $126.7 \mathrm{~d}$ \\
\hline 114 & $10.6 \mathrm{~b}$ & $18.3 \mathrm{bc}$ & $15.4 \mathrm{c}$ & $84.7 \mathrm{bc}$ & $131.8 \mathrm{c}$ \\
\hline 135 & $10.5 \mathrm{c}$ & $19.0 \mathrm{~b}$ & $16.3 \mathrm{~b}$ & $86.1 \mathrm{ab}$ & $137.8 \mathrm{~b}$ \\
\hline 183 & $10.1 \mathrm{c}$ & $20.0 \mathrm{a}$ & $17.5 \mathrm{a}$ & $88.0 \mathrm{a}$ & $147.3 \mathrm{a}$ \\
\hline $\mathrm{F}$ & $23.3 * *$ & $130.7^{* *}$ & $143.8^{* *}$ & $123.9^{* *}$ & $269.6^{* *}$ \\
\hline CV $(\%)$ & 2.01 & 1.84 & 2.20 & 1.06 & 1.42 \\
\hline
\end{tabular}

** significant at the $1 \%$ probability level by the $\mathrm{F}$ test. Means followed by the same letter in a column do not differ from each other at the $5 \%$ probability level by the Tukey test. Brix $=$ Sugar content (gram of sucrose in 100 grams of solution), POL $=$ Sucrose content expressed as percentage, $\mathrm{TRS}=$ Total reducing sugars, $\mathrm{CV}=$ coefficient of variation. 
I. hederifolia plants reduced this characteristic by $72 \%$ (Figure 4).

\section{DISCUSSION}

In both experiments, the importance and the eventual interference of the two weed species in the sugarcane occurred at different times. Initially, I. hederifolia was a more problematic species, and later, it was $M$. aegyptia. This observation may be related to the difference in the vegetative cycles possessed by the species. According to Guzzo et al. (2010), I. hederifolia plants present the
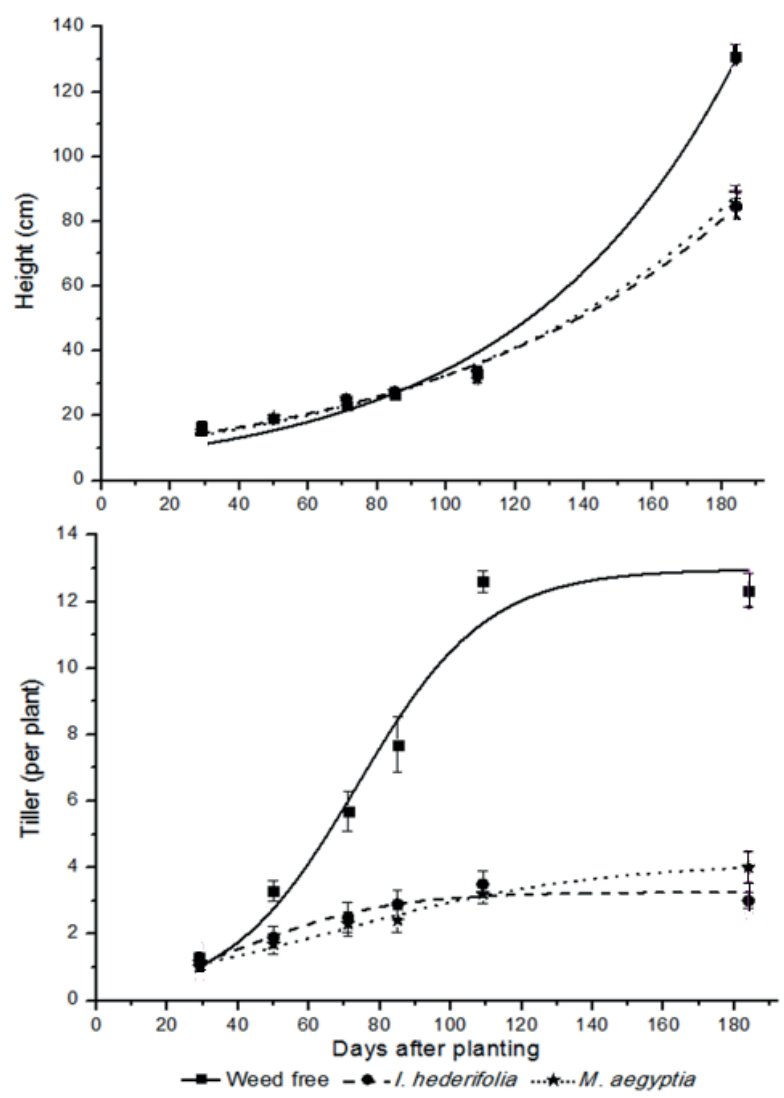

Figure 3 - Sugarcane plant height $(\mathrm{cm})$ and tillers weed-free $(\square)$ or competing with Ipomoea hederifolia $(\bullet)$ and Merremia aegypti (*). Height: Weed-free: $\mathrm{Y}=6.99 * \exp \left(0.015^{*} \mathrm{x}\right)$, $\mathrm{R}^{2}=0.98$; I. hederifolia: $\mathrm{Y}=10.44 * \exp (0.011 * \mathrm{x}), \mathrm{R}^{2}=-0.99 ; M$. aegyptia: $\mathrm{Y}=9.92 * \exp (0.011 * \mathrm{x}), \mathrm{R}^{2}=0,98$. Tiller: Weed-free: $\mathrm{Y}=12.97 /(1+\exp (-0.05(\mathrm{x}-73.68))), \mathrm{R}^{2}=0.95 ;$ I. hederifolia: $\mathrm{Y}=3.25 /(1+\exp (-0.04 *(\mathrm{x}-42.01))), \mathrm{R}^{2}=0.89 ;$ M. aegyptia: $\mathrm{Y}=4.16 /(1+\exp (-0.02 *(\mathrm{x}-67.19))), \mathrm{R}^{2}=0.98$. Vertical bars denote the error of the mean $(n=6)$. maximum accumulation of dry matter between 133 and 146 DAP. After this period, the plants reduce their production of dry mass and the absorption of nutrients, as they enter in senescence. On the other hand, Martins et al. (2010) observed that $M$. aegyptia obtains the maximum accumulation of dry matter between 146 and 160 DAP, i.e., later than I. hederifolia.

For the variables analyzed in the sugarcane, studies corroborate that the presence of weeds interferes negatively with the height and the formation of sugarcane tillers. For the height, these reductions vary between 30 and 60\% (Durigan et al. 2004, Nawaz et al. 2015). Specifically, under predominant infestation by $M$. aegyptia, a $66 \%$ reduction in stalk height was observed in cultivar SP81-3250 (Correia et al. 2010), more than that observed here in sugarcane coexisting with this same species (39\%). For tiller number in billetplanted sugarcane with a predominance of $I$. hederifolia, the reduction was 34\% lower than observed here (Silva et al. 2009). With a prevailing infestation by $M$. aegyptia, also in billet-planted sugarcane, a reduction of $80 \%$ in the tiller number was observed (Correia et al. 2010), as seen in this work. These oscillations may occur depending on the cultivar used as well as the production/planting system used. Takim et al. (2014) found a reduction of $52 \%$ of tillers in ratoon sugarcane and $66 \%$ in plant sugarcane with weed coexistence, whereas Nawaz et al. (2015) found a reduction of $27.8 \%$ in the tiller number.

Affecting tiller formation, consequently, changes the final yield of the crop. The reduction in the final productivity of cane is also quite variable, being 11 to $97 \%$ (Kuva et al. 2001, Takim et al. 2014). For billet-planted sugarcane, yield reductions of $11 \%$ were observed with a predominance of Ipomoea spp. and Merremia spp. or $46 \%$ with a predominance of $I$. hederifolia, different from the $60 \%$ observed here (Silva et al. 2009, Carvalho et al. 2011). 


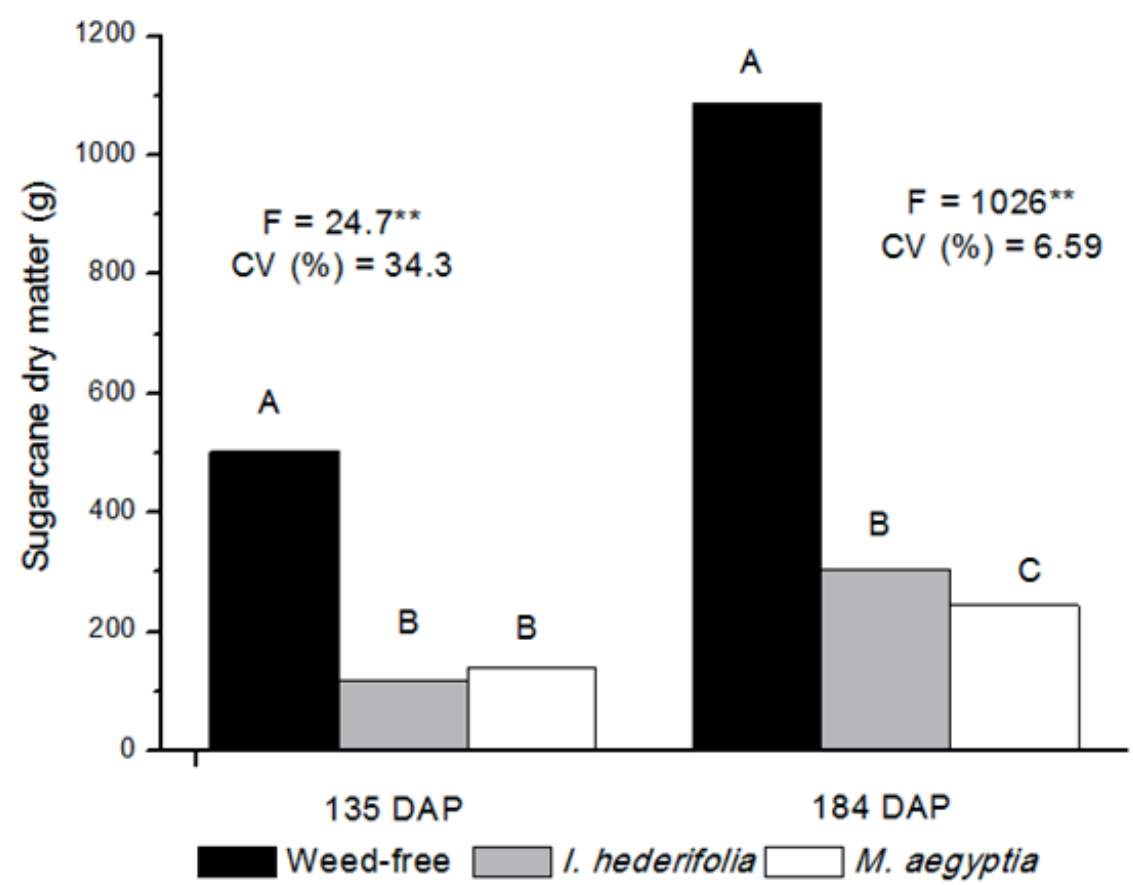

Figure 4 - Sugarcane dry matter (g) weed-free (black bar) and competing with Ipomoea hederifolia (gray bar) and Merremia aegyptia (white bar) at 135 and 184 days after planting. Weeds growing in plots planted with three sugarcane plants $\mathrm{m}^{-2}$. The different letters indicate significant differences according to the Tukey test at $5 \%(n=6)$.

Comparing the different systems of sugarcane planting, two main differences should be highlighted. The first concerns the quantity of the nutrient reserves. In the OES system, the seedlings have lower reserves than in the billeting system because only buds are planted, whereas sugarcane stalks are planted in the billeting system. The second point concerns the sugarcane's initial demand for environmental resources, which in the OES system is much earlier than in the billeting system, precisely because the bud does not have large amounts of nutrient reserves, water, etc. This helps explain why, in some occasions, weed interference will be greater in the OES cane.

The consequence of this greater interference is reflected in the periods of interference encountered in this work and in the quality characteristics of the sugarcane. For periods of interference, Kuva et al. (2001), who studied the same periods in billetplanted sugarcane, found PBI, TPIP, and CPIP values, respectively, of 89,138 , and 49 days. In another study, Kuva et al. (2003) found a PBI of 74, TPIP of 127, and CPIP of 53 days. Clearly, these critical periods of interference are lower than those found here, with values at least 54 days greater for the OES cane than the billet-planted sugarcane. Also, the PBI in the OES system (35 DAP) occurred much earlier than in the billeting system, due to the greater interference of the cultivated weeds.

For the qualitative characteristics of sugarcane, Piza (2016) found no interference in the purity, fiber, POL, and TRS in their study under a conventional system in sugarcane coexisting with I. hederifolia. Similarly, Nawaz et al. (2015) did not find significant interference in sugarcane due to the coexistence of weeds when analyzing the percentage of recoverable sugars. In the present study, for weed coexistence with OES, we found alterations in the qualitative characteristics of the cane produced, demonstrating again the greater 
susceptibility of this planting system to interference. The percentage of cane fiber increased as the periods of coexistence increased. In contrast, the other characteristics were reduced. The sugarcane may, in this case, have invested more photoassimilates for support because it was competing with climbing species and reduced the allocation of resources to, for example, sucrose formation. Therefore, losses in the OES system can be much higher than in billet-planted cane if not addressed, for example, by early management of weeds. Notably, this is the first study in the literature to observe these results, which are fundamentally important to weed management in the OES sugarcane cultivation system.

In conclusion, the PBI, TPIP, and CPIP of weeds in sugarcane planted in the OES system were, respectively, 35, 138, and 103 days, with the CPIP being longer than those observed for billet-planted cane. The presence of weeds in the OES planting system during the entire sugarcane cycle reduced productivity by $60 \%$ and affected the qualitative characteristics of production. The two most important species of the weed community reduced sugarcane developmental characteristics such as tillering and height, with I. hederifolia being more important at the beginning of the crop cycle and M. aegyptia at the end.

\section{ACKNOWLEDGMENTS}

The authors would like to thank the funding sources that supported this work in name of Fundação de Amparo à Pesquisa do Estado de São Paulo (FAPESP) [grant number 2014/24564$3]$ and Conselho Nacional de Desenvolvimento Científico e Tecnológico (CNPq) [grant number 140943/2014-5].

\section{REFERENCES}

AZANIA AAPM, AZANIA CAM, GRAVENA R, PAVANI MCMD AND PITELLI RA. 2002. Sucarcane (Saccharum spp.) straw interference in emergence of weed species of the Convolvulaceae family. Planta Daninha 20: 207-212.

BHULLAR MS, WALIA SS, SINGH S, SINGH M AND JHALA AJ. 2012. Control of morningglories (Ipomoea spp.) in sugarcane (Saccharum spp.). Weed Tech 26: 7782.

CARVALHO FT, QUEIROZ JRG AND TOLEDO REB. 2011. Efficacy of amicarbazone herbicide in controlling morningglories in sugar cane (Saccharum spp.) crop. Rev Bras Herb 10: 183-189.

CAVENAGHI AL, ROSSI CVS, NEGRISOOLI E, COSTA EAD AND TOLEDO REB. 2007. Performance of amicarbazone applied on sugarcane straw. Planta Daninha 25: 831-837.

CONAB. 2017. Acompanhamento da Safra Brasileira de Cana-de-açúcar, Safra 2017/18. Disponível em: $<$ http://www.conab.gov.br/OlalaCMS/uploads/ arquivos/17_08_24_08_59_54_boletim_cana_ portugues_-_2o_lev_-_17-18.pdf>. Acessado em 27 de Agosto de 2017.

CORREIA NM AND KRONKA JRB. 2010. Chemical control of plants of the genera Ipomoea and Merremia in sugarcane. Planta Daninha 28: 1143-1152.

DALLEY CD AND RICHARD JREP. 2007. Sugarcane Response to Bermudagrass Interference. Weed Tech 21: 941-946.

DURIGAN JC, TIMOSSI PC AND LEITE GJ. 2004. Chemical control of Cyperus rotundus, with and without sugarcane straw cover. Planta Daninha 22: 127-135.

GUZZO CD, CARVALHO LB, BIANCO MS AND BIANCO S. 2010. Growth and mineral nutrition of Ipomoea hederifolia. Planta Daninha 28: 1015-1021.

KHAN B, JAMA M AND AZIM H. 2004. Effect of weeds on cane yield and content of sugarcane. Pak J Weed Sci Res 10: 47-50.

KOPPEN W. 1948. Climatologia: con un estudio de los climas de la tierra. Fondo de Cultura Econômica. México, 479 p.

KUVA MA, GRAVENA R, PITELLI RA, CHRISTOFFOLETI PJ AND ALVES PLCA. 2001. Interference periods of weeds in the sucarcane crop. II - Brachiaria decumbens. Planta Daninha 19: 323-330.

KUVA MA, GRAVENA R, PITELLI RA, CHRISTOFFOLETI PJ AND ALVES PLCA. 2003. Interference periods of weeds in the sucarcane crop. III - Brachiaria decumbens and Panicum maximum. Planta Daninha 21: 37-44.

KUVA MA, PITELLI RA, CHRISTOFFOLETI PJ AND ALVES PLCA. 2000. Interference periods of weeds in the sucarcane crop. I - Purple nutsedge. Planta Daninha 18: 241-251.

KUVA MA, PITELLI RA, SALGADO TP AND ALVES PLCA. 2007. Phytosociology of weed community in noburn sugar cane agroecosystem. Planta Daninha 25: 501511. 
LANDELL MGA ET AL. 2012. Sistema de multiplicação de Cana de Açúcar com uso de mudas pré brotadas (MPB) oriundas de gemas individualizadas. Documentos IAC, $109,17 \mathrm{p}$.

LENCSE RJ AND GRIFFIN JL. 1991. Itchgrass (Rottboellia cochinchinensis) Interference in Sugarcane (Saccharum sp.). Weed Tech 5: 396-399.

MARTINS D, VELINI ED, MARTINS CC AND SOUZA LS. 1999. Broadleaf weed emergence in soil covered with sugar cane straw. Planta Daninha 17: 151-161.

MARTINS TA, CARVALHO LB, BIANCO MS AND BIANCO S. 2010. Accumulation of dry matter and macronutrients in Merremia aegyptia plants. Planta Daninha 28: 1023-1029.

MEIRELLES GLS, ALVES PLCA AND NEPOMUCENO MP. 2009. Weed interference periods in ratoon sugarcane. Planta Daninha 27: 67-73.

MUELLER-DUMBOIS D AND ELLENBERG H. 1974. Aims and Methods of Vegetation Ecology. New York: J Wiley \& Sons, $547 \mathrm{p}$.

NAWAZ M, KHAN S, CHATTA MU, KHAN M AND BILIAL M. 2015. Effect of sowing techniques and weed crop competition periods on the performance of spring planted sugarcane (Saccharum officinarum L.). Int J Mod Agric 4: 49-50.

NEGRISSOLI E, VELINI ED, ROSSI EVS, CORREIA TS AND COSTA AGF. 2007. Tebuthiuron and straw cover association for weed control under the raw sugar cane system. Planta Daninha 25: 621-628.

PITELLI RA AND DURIGAN JC. 1984. Terminologia para períodos de controle e convivência das plantas daninhas em culturas anuais e bianuais. In: Congresso Brasileiro De Herbicidas e Plantas Daninhas, 15, Belo Horizonte. Resumos. Belo Horizonte: SBHDE, $37 \mathrm{p}$.

PIZA CST, NEPOMUCENO MP AND ALVES PLCA. 2016. Period prior to interference of morningglory in sugarcane. Científica 44: 543-548.

SILVA IAB, KUVA MA, ALVES PLCA AND SALGADO TP. 2009. Interference of a weed community with predominance of Ipomoea hederifolia on sugar cane ratoon. Planta Daninha 27: 265-272.

TAKIM FO, FADAYOMI O, ALABI MA AND OLAWUYI OJ. 2014. Impact of natural weed infestation on the performance of selected sugarcane varieties in the southern Guinea savanna of Nigeria. Eth J Env Studies Manag 7: 279-288. 